\title{
Echolocation, as a method supporting spatial orientation and independent movement of people with visual impairment
}

\begin{abstract}
Kamila Miler-Zdanowska, Echolocation, as a method supporting spa-tial orientation and independent movement of people with visual impairment. Interdisciplinary Contexts of Special Pedagogy, no. 25, Poznań 2019. Pp. 353-371. Adam Mickiewicz University Press. ISSN 2300-391X. DOI: https://doi.org/10.14746/ikps.2019.25.15
\end{abstract}

People with visual impairment use information from other senses to gain knowledge about the world around them. More and more studies conducted with the participation of visually impaired people indicate that data obtained through auditory perception is extremely important. In this context, the ability of echolocation used by blind people to move independently is interesting. The aim of the article is to present echolocation as a method supporting spatial orientation of people with visual impairment. The article presents the results of empirical studies of echolocation. It also presents the benefits of using this ability in everyday life and signals research projects related to the methodology of teaching echolocation in Poland. People with visually impaired to get knowledge about the world around them use information from other senses. Many studies conducted with the participation of visually impaired people indicate that data obtained through hearing are extremely important. In this context, the ability of echolocation used by blind people to move independently is interesting. The aim of the article is to present echolocation as a method supporting spatial orientation of people with visual disabilities. The article presents the results of empirical studies on echolocation. It also presents the benefits of using this skill in everyday life and signals research projects on the methodology of teaching echolocation in Poland.

KEY WORDS: echolocation, spatial orientation, visual impairment echolocation, spatial orientation, visual disability 
The reality in which we live is strongly oriented towards looking at and seeing. Well-functioning vision provides us with a lot of information about the world. It allows for a detailed perception of space, the objects it contains, and the relationships between them. It also enables the perception of movement and changes taking place in the environment. Vision is also crucial for assessing the position of one's body in space and for moving there. Therefore, in a situation of blindness or poor vision, when eyesight cannot be the primary source of information about the world, other senses and other strategies for obtaining such information should be used. In the case of people with visual impairment, properly functioning senses of hearing, touch, proprioception, balance, and smell are of key importance. ${ }^{1}$ According to research conducted around the world on the perception of the world by blind people, sound plays a key role in creating their image of the world. Blind people convert the received sound signal into a spatial image in the visual cortex responsible for vision. Therefore, blind people create a fairly accurate picture of the environment in their brains, even if they do not use eyesight but reflected sounds. ${ }^{2}$ This skill is extremely needed and useful to orientate in space and during independent movement of people with visual impairment. The basis of this auditory spatial

${ }^{1}$ K. Miler-Zdanowska, Czynniki warunkujące nauczanie orientacji przestrzennej i samodzielnego poruszania się osób z niepetnosprawnością wzroku, [in:] K. Czerwińska, M. Paplińska, M. Walkiewicz-Krutak (eds.), Tyflopedagogika wobec współczesnych przemian przestrzeni edukacyjnej, Wydawnictwo APS, Warsaw 2015, p. 296.

${ }^{2}$ Research with the use of functional magnetic resonance imaging (fRMI) was conducted by Melvyn Goodale, a professor of psychology, director of the Brain and Mind Institute at the University of Western Ontario in Canada. Together with his team, he studied the functional organization of visual pathways in the cerebral cortex. As a result of experiments conducted with the participation of Daniel Kish and Brian Bushway (blind men using echolocation to move), he discovered that only in them the visual cortex in the brain is activated while hearing reflected sounds. However, in sighted people exposed to the same procedure, only auditory cortex is activated. Professor Goodale has determined that echolocation can be used in a very similar way to eyesight. More information on this topic can be found in: M.A. Goodale, Po co mózg widzi?, „Charaktery”, 2013, 2, pp. 44-45. 
orientation of blind people is the auditory sensation arising from the reflection of sound from an obstacle. According to Urszula Jorasz, probably the most important is the assessment of the so-called "reflection tone", which results from the interference of sound reflected directly from the obstacle. ${ }^{3}$

This ability to detect, interpret and locate an obstacle based on the echo created by reflection of independently produced sounds from surrounding objects is called echolocation. ${ }^{4}$ The term is also defined as "a method of interpreting the sounds generated by echoes from surrounding objects in order to determine the place in which the objects are situated" 5 , as well as "a technique that consciously involves the senses, especially the sense of hearing, in perceiving and gathering precise information about structures, forms, features of objects in such a way that an object or a group of objects presented in a given environment can be identified". ${ }^{6}$ This skill is available to all blind and sighted people. This is confirmed by scientific research conducted in the world, in which sighted people after several weeks of training were able to aurally locate objects in space. ${ }^{7}$ However, this ability is more often used and improved by

${ }^{3}$ U. Jorasz, Wykłady z psychoakustyki. Wydawnictwo Naukowe UAM, Poznań, 1998, p. 126.

${ }^{4}$ The term echolocation was first used by Donald Griffin, a zoologist who studied the behaviour of bats. Because of the fact that the same mechanism was observed in blind people, it was adapted to describe this type of ability in people. A.J. Kolarik, S. Cirstea, S. Pardhan, B.C., Moore, A summary of research investigating echolocation abilities of blind and sighted humans. 2014, "Hear Res", 10, p. 62.

${ }^{5} \mathrm{~T}$. Johnson, Beginner's guide to echolocation for the blind and visually impaired. Learning to See with Your Ears. Create Space Independent Publishing Platform, 2012, p. 16.

${ }^{6}$ D. Kish, J. Hook, Echolocation and Flash Sonar. American Printing for the Blind, 2016, p. 27.

7 The study conducted by Rojas et al. on a group of ten sighted volunteers showed that sighted people are able to learn to use echolocation to detect obstacles. This learning consisted of systematic, daily training with closed eyes. A description of the study was included in: J.A.M, Rojas J.A., Hermosilla, R.S, Montero, P.L.L., Espí. Physical analysis of several organic signals for human echolocation: hand and 
people with visual impairment because of its useful nature in their daily functioning as one of the ways to obtain information about the surrounding world.

\section{Use of echolocation by people with visual impairment}

People with visual impairment more or less consciously use echolocation in everyday life. Very young blind children are focused on the perception of sound sensations from the environment (sounds made by objects, people, phenomena, etc.) or on the spontaneous production of sounds by shuffling their feet, clapping their hands or making different mouth sounds. These are their first spontaneous manifestations of using echolocation. These behaviours are not always understood by their surroundings and are often not strengthened or developed. Auditory reception of random sounds from the environment (e.g. bus brake squealing, noises from a construction site, sound of closed doors, etc.) is passive echolocation ${ }^{8}$. It allows locating the sound source, determine its distance from a person and helps to determine the position of our body in relation to the sounds emitted from the environment. This type of echolocation is usually used to obtain information about the presence of large objects in the environment (e.g. cars, building walls, bus shelters, etc.) or general information about the size and shape of the room. However, when a blind person wants to identify small objects in space precisely, get information about their size, shape, material of which they are made by hearing, they should independently and

finger produced pulses. "Acta Acustica united with Acustica", 2010, 96, pp. 1069-1077. The study of S. Teng, D. Whitney also demonstrated that sighted people (eleven sighted people participated in the study) are able to achieve echolocation skills at the same level as blind people as a result of training. S. Teng, D. Whitney, The acuity of echolocation: Spatial resolution in the sighted compared to expert performance, Journal of Visual Impairment \& Blindness. 2011, 105(1), pp. 20-32.

8 D. Kish, J. Hook, Echolocation and Flash Sonar. American Printing for the Blind, 2016, p. 40. 
consciously produce sounds by clapping their hands, clicking with their fingers or smacking their lips. In this way, the sound emitted in the desired direction hits the object and the echo arising from the reflection returns to the person making the sound. The ability to interpret the returning echo is very important here. Based on its assessment, people with visual impairment are able to create a mental representation of the environment. Developing the ability of active echolocation requires a lot of exercise and commitment.

Both types of echolocation can be used together in an integrated way. Passive echolocation provides a person with visual impairment with rather general, usually not very precise images. In contrast, active echolocation allows getting more specific perception. In this sense, we can think of passive echolocation as a peripheral vision system that provides a constant, broad, overall picture of the environment, acting as a kind of alarm system. In turn, active echolocation is comparable to the central visual system in the sense that it allows noticing specific objects or interesting elements in more detail and from further distances..$^{9}$ The condition of using passive echolocation is an efficient hearing organ, which is sensitive to sounds, while in the case of active echolocation, it is very important to be able to emit sound (smacking one's lips, snapping one's fingers, clapping one's hands, etc.) and be able to interpret the sound reflected from objects. The conducted studies of echolocation ${ }^{10}$ have demonstrated that of all human-made signals, sounds produced by the mouth (smacking one's tongue, smacking one's lips) are best heard in noise or din. However, few people with visual impairment can emit this sound correctly. As an alternative, many people clap their hands or snap their fingers. Based on the performed tests,

${ }^{9}$ More information on this topic can be found in: D. Kish, J. Hook, Echolocation and Flash Sonar. American Printing for the Blind, 2016, pp. 44-45.

10 The study conducted by Rojas and his team aimed to determine the most effective way of producing sounds for active echolocation. These studies were described in: J.A.M. Rojas, J.A. Hermosilla, R.S. Montero, P.L.L. Espi Physical analysis of several organic signals for human echolocation: hand and finger produced pulses. "Acta Acustica united with Acustica", 2010, 96, p. 1075. 
snapping one's fingers is more effective for echolocation than clapping one's hands. However, both clapping one's hands and snapping one's fingers is less useful in practice than smacking one's tongue due to the involvement of hands, which in the case of blind people are usually used when moving around to hold a white cane, a guide or a guide dog. ${ }^{11}$

Here, it should be strongly emphasized that during movement, echolocation should be used as a method supporting orientation in space of people with visual impairment and not as an independent technique (without the use of a white cane, a guide $d o g$, a guide or other devices supporting mobility).12

A properly developed echolocation skill can provide a visually impaired person with a lot of information about the spatial environment. According to the blind, the main advantage of echolocation is obtaining information about space that is not accessible by touch, which significantly improves their mobility and sense of direction, especially in unknown places. Echolocation significantly improves navigational abilities during movement. ${ }^{13}$

The skill of echolocation can be used by people with visual impairment in many everyday situations, and thus in numerous different places. Basically, two types of space in which people with visual impairment use echolocation can be distinguished. These are

11 Characteristics of the mentioned ways of movement of people with visual impairment has been described in: K. Miler-Zdanowska, Orientacja przestrzenna dzieci z dysfunkcja wzroku - droga do niezależności, [in:] Witczak-Nowotna J. (ed.), Wspomaganie uczniów z dysfunkcja wzroku w szkołach ogólnodostępnych. Edited by: Office for Persons with Disabilities of the University of Warsaw, Warsaw 2010, p. 53.

12 This important aspect is pointed out by Daniel Kish, the most famous blind echolocator in the world. The use of echolocation as an independent technique can even be dangerous for people with visual impairment, because it does not provide information about obstacles that are below the hips (small objects protruding above the ground, holes, unevenness etc.). Daniel Kish encourages moving with a white cane that, when used correctly, ensures a blind person safety and quite a lot of independence.

${ }^{13}$ K. Fiehler, I. Schiitz, T. Meller, L. Thaler, Neural Correlates of Human Echolocation of Path Direction During Walking. "Multisensory Research" 2015, 28, p. 197. 
a closed space (inside the building) and an open space (outside the building). In a closed space, or in an apartment, office, clinic, store, etc., using echolocation permits a determination of the shape, and size of the room, and acquisition of information whether the room is empty or filled with furniture. ${ }^{14}$ During movement in the corridor, it is possible to maintain straightness of the march, detect and locate the door (open and closed), stairs, as well as locate obstacles along the route. On the other hand, in an open space, or in a park, a forest, in a residential or commercial area or city centre, echolocation can facilitate the location of service outlets (e.g. a store, a clinic, an office, etc.), and the location of large facilities along the route (e.g. a bus stop, cars parked along the street, bushes, trees, benches, poles, etc.). During the movement on a pavement, parallel to street traffic, this skill can help to locate the ends of the building walls, fences or facilitate the detection of spaces between buildings (entrance gates, parking entrances, etc.), as well as efficiently detect and identify underground passages, tunnels, etc. ${ }^{15}$

\section{Selected studies concerning the subject of echolocation in people with visual impairment}

Issues regarding echolocation in people with visual impairments were and still are of interest to various groups of scientists. They were usually embedded in the field of acoustics, cognitive psychology and psychoacoustics. However, the development of neuroscience, attempting to explain human cognitive functioning based on the normal functioning of the brain, attracted scientists in the field of neuropsychology and information engineering to this area.

14 J. Kuczyńska-Kwapisz, Znaczenie dzwięku w orientacji przestrzennej niewidomych i słabo widzących. Normalizacja, 1997, 2, no. 12.

15 The aforementioned examples of echolocation are based on training materials as part of the EchoProViP project in Poland: L. Dyeker, O\&M - Flash sonar/ekkolokalisering. A tutorial for O\&M instructors in Denmark, IBOS, 2014 (unpublished materials). 
The first research reports concerning the use of sounds reflected from an obstacle for movement were recorded in 1793 by Lazzaro Spallanzani, but they concerned the use of this ability by bats. In subsequent observations of these animals, Charles Jurines in 1794 determined that if bats have plugged ears they are not able to use this ability and collide with an obstacle. One hundred and fifty years later, Donald Griffin showed that bats use their own emitted sound to navigate and locate victims using sounds. ${ }^{16}$

Simultaneously to the observations and discoveries of zoologists, the first reports on the use of echolocation skills in humans have been reported. In 1749 Denis Diderot described the case of a blind man who was able to locate various objects and estimate their distance. However, Diderot explained this ability as feeling the closeness of objects on the face and called this ability "face vision" ${ }^{17}$ Over the years, numerous researchers (Levy 1872, James 1890, Dressler 1893, Heller 1904, Javal 1905, Villey 1918, etc.) ${ }^{18}$, searched for the explanation of object locating skills possessed by blind people and tried to explain their mechanism by calling them "face vision", "the sixth sense", "the sense of obstacles". Subsequent experiments conducted by Włodzimierz Dolański in 1930 demonstrated that the basis of the sense of obstacles is hearing, and not as previously thought the touch created by air pressure. ${ }^{19}$

16 Wiener W.R., Lausen G.D. Audition for the Traveler Who Is Visually Impaired, [in:] B.B. Blasch, W.R. Wiener, R.L. Welsch (eds.), Foundations of Orientation and Mobility, 1997, A.F.B. Press: New York, p. 146.

17 Kolarik A.J., Cirstea S., Pardhan S., Moore B.C., A summary of research investigating echolocation abilities of blind and sighted humans. 2014, "Hear Res", 10, p. 63.

18 A detailed description of the undertaken research is included in: Wiener W.R., Lausen G.D., Audition for the Traveler Who Is Visually Impaired, in B.B. Blasch, W.R. Wiener, R.L. Welsch (eds.), Foundations of Orientation and Mobility, 1997, A.F.B. Press: New York, 146. These researchers formulated several theories explaining the mechanism of the sense of obstacles: Truschel's acoustic theory, Kunz's compression theory, Krogius's thermal theory, Villey's auditory theory, and Heller's complex reception of impressions theory.

19 Włodzimierz Dolański conducted several experiments during which he investigated the detection of a shield approached to the exposed face, with the use 
A breakthrough in the study of echolocation and the explanation of its mechanisms was a series of pioneering studies conducted at the Cornell Psychological Laboratory in the 1840s. In the first study, Karl M. Dallenbach (a professor at the Cornell University), Michael Supa (a blind echolocator), and Wilton Cotzin (a sighted echolocator) found that face vision is actually an auditory ability and that acoustic stimulation is necessary to detect and locate objects in the environment. ${ }^{20}$

Further studies conducted in various research facilities confirmed that both blind and sighted people have echolocation abilities. The most comprehensive study in the field of this issue was conducted in 1960 by Charle E. Rice. His research involved blind people (5 people blind from birth), people who became blind at the age of above 3, as well as sighted people. As a result of the study, it was found that both blind and sighted people are able to echolocate at a comparable level. ${ }^{21}$ Similar research was also conducted by Kellogg and he found that blind people have a better ability to detect reflected sound (echoes) than sighted people, and that "obstacle detection" is better in people blind from birth than those who became blind later or are partially sighted. In addition, modern research conducted by Santani Tenga and David Withnej demonstrate that echolocation abilities in some sighted people after training are at a similar level as in the case of blind people, and that in both the

of earmuffs, a mask and cotton wool in the ears. W. Dolański, Czy istnieje "zmyst przeszkód" u niewidomych. PWN, Warszawa 1954, pp. 36-41.

${ }^{20}$ Two sighted people and two blind people participated in the study. Subjects were asked to approach the obstacle and report it as soon as they were able to detect it, and then stop as close as possible to the obstacle. When the participants' ears were covered (headphones with loud music were applied), the ability to detect the obstacle and assess its distance disappeared. Supa, M. Cotzin, M., Dallenbach, K.M., Facial vision, the perception of obstacles by the blind. American Journal of Psychology, 57, 1944, pp. 133-183.

${ }^{21}$ J. Kuczyńska-Kwapisz, E. Śmiechowska-Petrovskij, Orientacja przestrzenna $i$ poruszanie się osób z niepetnosprawnościq wzroku. Wspótczesne techniki, narzędzia i strategie nauczania, Wydawnictwo UKSW, Warsaw 2017, p. 43. 
blind and the sighted population these abilities show individual variability.22

In the following years, research on echolocation was focused on the acoustic properties of both the echo produced by echolocators, as well as the acoustic properties of the environment. In the 1980s Bo. N. Schenkman analysed the impact of several factors (sound sources, object physical parameters and type of tasks) on the abilities of the blind and examined the psychoacoustic mechanisms of echolocation. As a result of the conducted study, it was found that detecting objects in the environment based on the sounds produced by the white cane (in contact with the ground) is more difficult for blind echolocators than smacking their tongue. Studies have also demonstrated that the length of the emitted sound signal affects the effective detection of objects in the environment. Short signals are more helpful in locating objects, while continuous signals are better for determining physical characteristics of objects..$^{23}$

In the late 1990s Claudia Arias and O.A. Ramos studied the effect of sound pitch on detecting objects in space. To conduct the study, they used both smacking one's tongue and sound emitted from a loudspeaker (alone or with echo). The tasks used in the study included detecting various objects (distinguishing sounds with and without echo) and distinguishing changes in the distance between the sound source and the object. As a result of the conducted study, it was found that sound pitch is important for faster location and detection of objects in space and for distinguishing their distances. ${ }^{24}$ Subsequent studies of human echolocation were aimed at checking the impact of movement, and actions on echolocation

22 S. Theng, D. Whitney, The acuity of echolocation: Spatial resolution in the sighted compared to expert performance, Journal of Visual Impairment \& Blindness. 2011, 105(1), pp. 20-32.

${ }^{23}$ C. Arias, F. Bermejo, M.X. Hüg, N. Venturelli, D. Rabinovich, A.O. Skarp, Echolocation: An Action-Perception Phenomenon, "New Zealand Acoustics", 2012, 25(2), p. 22.

24 Arias, C., Ramos, O.A. Psychoacoustic tests for the study of human echolocation ability. Appl. Acoust., 1997, 51, pp. 399-419. 
abilities. This type of study was conducted by Lawrence D. Rosenblum and he demonstrated a beneficial effect of motor activity on the accuracy of echolocation. ${ }^{25}$

Interesting studies of echolocation were conducted in 2010 and 2016 by Bo N. Schenkmen and Mats E. Nilsson. In both studies, attempts were made to determine which components of the acoustic stimulus affect echolocation. Blind and sighted people (ten blind people and ten sighted people between 30 and 60 years old) were asked to indicate which of the two presented sounds is the sound from the reflected obstacle. The presented sounds differed in both the sound volume and pitch parameter. As a result of the study, it was found that a person with visual impairment, located in close proximity to the object for echolocation usually uses the pitch of the sound, while the volume of the sound is an additional source of information.

The researchers also found that the size of the room affects the distance at which echolocation can be used. In large rooms, e.g. in a conference room, this distance may be greater than in very small rooms, e.g. in an anechoic chamber. In this experiment, blind people obtained better results than sighted people. ${ }^{26}$ The second of the conducted studies also confirmed the benefits of using the "excess of information" principle in echolocation. This means that for the blind, the presence of a large amount of acoustic information makes perception tasks (e.g. obstacle detection) easier than when there is little information. Even hearing levels in both ears are also very important for echolocation. ${ }^{27}$

25 Blind people who used echolocation while moving achieved better results in detecting obstacles than those who used stationary echolocation. These studies were described in: A.J. Kolarik, S. Cirstea, S. Pardhan, B.C. Moore., A summary of research investigating echolocation abilities of blind and sighted humans. 2014, "Hear Res", 10, pp. 60-68.

${ }^{26}$ A detailed description of the study can be found in: B. Schenkman, M.E. Nillson, Human echolocation: Blind and sighted persons' ability to detect sounds recorded in the presence of a reflecting object, "Perception", 2010, 39, p. 485.

27 B. Schenkman, Human echolocation in different situations and rooms. The Journal of the Acoustical Society of America, 2017, 141(5), pp. 3452-3452. 
Yet other studies of the properties of the most common pulses generated during echolocation were conducted by Juan A.M. Rojas with his team. During the study it was investigated which sounds produced by humans for echolocation are the most effective. Clapping one's hands, snapping one's fingers, playing castanets, and smacking one's tongue were analysed. As a result of the conducted study, it was found that clapping one's hands and snapping one's fingers are the most intuitive and commonly produced sounds of the human body. However, detailed physical properties of the sounds produced in this way vary greatly from person to person, and it is impossible to reproduce the same sound each time, which can significantly affect the detection of small obstacles.

Therefore, clapping one's hands and snapping one's fingers can be used as an alternative way of producing sounds to detect distant obstacles. ${ }^{28}$ The results of the conducted tests confirm that the best sound for echolocation is the so-called smacking one's tongue. It involves "a rapid, horizontal retraction of the tongue towards the back of the mouth, previously touching the palate, above the upper teeth, with slightly parted lips" ${ }^{29}$ The tactile aspect of smacking one's tongue, which is felt as a vibration on the tongue, teeth, jaws and skull bones, is also very important. These types of smacking are very effective in detecting and locating obstacles located at the height of the echolocating person's head and in detecting very small objects in space.

In further studies of echolocation in the field of acoustics, attempts were made to determine the most favourable acoustic fea-

28 Detailed acoustic analyses of individual types of sounds produced during echolocation can be found in: J.A.M. Rojas, J.A. Hermosilla, R.S. Montero, P.L.L. Espí, Physical analysis of several organic signals for human echolocation: hand and finger produced pulses. "Acta Acustica united with Acustica", 2010, 96, pp. 1073-1075.

${ }^{29}$ P. Witek, A. Rozborska, A. Waszkielewicz, M. Rotnicki, L. Brayda, Echolokacja - mit czy istotny element rehabilitacji osób z niepetnosprawnościa wzroku, [in]: Paplińska M., Walkiewicz-Krutak M. (eds.), Tyflopedagogika wobec wspótczesnych potrzeb wspomagania rozwoju, rehabilitacji i aktywizacji społecznej, Wydawnictwo APS, Warsaw 2017, p. 245. 
tures of the emitted sounds. Liam J. Norman and Lowrence Thaler in 2017 conducted a study in a group of 12 blind people (8 women and 4 men aged from 18 to 41 ) consisting in assessing the presence of the object in the environment and the distance of the object based on echo recordings at different frequencies. As a result of the conducted experiment, it was found that the use of emission of sounds containing higher spectral frequencies improved echolocation performance in the object detection task. Blind people generating clicks of higher spectral frequencies detected and located objects in the environment much better than blind people using clicks of lower frequencies. Sound emissions containing higher spectral frequencies produced louder echoes that were more audible. ${ }^{30}$

Researchers involved in echolocation, in addition to the acoustic aspect of echolocation were also interested in the effects of the age of becoming blind on the ability to echolocate, as well as learning this ability by sighted people. The studies in this area were conducted by Sanatani Teng and David Whitney. The study involved sighted and blind people with various experience in using echolocation. The task of the examined people was to determine the location of plastic discs several times by means of smacking their tongue (discs were presented at different distances and in different positions). The results of the research showed that the best and most precise echolocation was demonstrated by people who had experience in the use of echolocation. Moreover people who lost their vision in early childhood showed echolocation skills similar to bats. Therefore, the time of vision loss and echolocation experiences are important for the presented echolocation skills (the study showed a strong correlation between the age of losing vision and the ability to echolocate, and a consistent improvement of the obtained results by practice). ${ }^{31}$

${ }^{30}$ L.J. Norman, L. Thaler, Human Echolocation for Target Detection Is More Accurate With Emissions Containing Higher Spectral Frequencies, and This Is Explained by Echo Intensity, "i-Perception”, 2018, 9(3), pp. 16-18.

31 S. Theng, D. Whitney, The acuity of echolocation: Spatial resolution in the sighted compared to expert performance, Journal of Visual Impairment \& Blindness. 2011, 105(1), pp. 20-32. 
Yet another study comparing echolocation performance in sighted and blind people was conducted by Andrew J. Koralik with his team in 2012. Research has demonstrated that blind people are more sensitive to information they do not generate originating from sounds reflected from an obstacle than sighted people (e.g. sounds emitted from a loudspeaker) and are better performing the task of discrimination at a distance, when only signals from the echo are available than sighted people. Moreover, a large individual variation in echolocation skills was observed in both groups..$^{32}$

In recent years, within research on echolocation, extremely interesting studies with the use of the method of neuroimaging appear. Two independent teams of scientists (a team of American psychologists from the University of Western Ontario in Canada and a team from the University of California) observed the brain activity of blind people who, based on the sounds of the reflected echo, were able to assess the properties of objects (metal, woven fabric, wood, etc.). In both studies, cortical activity of the brain was also observed in areas typical for visual perception. The discoveries of "brain plasticity" made during research are of great importance for both blind people (echolocation can be used in a similar way to eyesight) but also allow a better understanding of the brain work in sighted people. ${ }^{33}$

In recent years there has been a great interest in the echolocation skills of blind people. It translates into the research interests of scientists around the world. However, the biggest limitation of research are few research samples (from a few to a dozen or so people), which means that the research results cannot be extended to the entire population of people with visual impairment. Despite

32 L.J. Norman, L. Thaler, Human Echolocation for Target Detection Is More Accurate With Emissions Containing Higher Spectral Frequencies, and This Is Explained by Echo Intensity, "i-Perception", 2018, 9(3), pp. 1-18.

33 The mentioned studies were partially described in the first part of the article. More information on can be found in: M.A. Goodale, Po co mózg widzi?, "Charaktery", 2013, 2, p. 45. 
this, the conducted studies allowed for understanding the mechanism of echolocation, factors that determine its effectiveness, acoustic mechanisms and its neurological basis.

\section{Echolocation of people with visual impairment in Poland, practical activities}

The research on human echolocation described above demonstrate the theoretical foundations of this issue. They are extremely important for establishing the methodology of teaching this skill to people with visual impairment. Blind echolocators ${ }^{34}$ develop their echolocation abilities in an intuitive way, while research clearly indicates that the effectiveness of echolocation increases with its practical, systematic use. In Poland, for several years a team of scientists from the Lodz University of Technology ${ }^{35}$ has been conducting intensive research on human echolocation, which in addition to research findings has a practical dimension. Researchers compared echolocation skills (obstacle detection from different distances) in a natural environment in a group of blind children, blind adults and sighted adults. They also compared the accuracy of recognizing the same scenarios using binaural recordings and a mobile application. The obtained research results will be used to create several mobile applications supporting the development of echolocation. Each of the designed applications will be devoted to a different issue. The first one will be a tool for learning to distinguish between sounds at a basic level. The second one will constitute support for learning passive and active echolocation (at various levels of advancement) for people with visual impairment, as well as support for spatial

34 The best-known blind echolocator is Daniel Kish. As part of the Word Access for the Blind, he conducts training in echolocation for instructors and blind people.

35 Bujacz M. et al. EchoVis: Training Echolocation Using Binaural Recordings - Initial Benchmark Results. In: Miesenberger K., Kouroupetroglou G. (eds) Computers Helping People with Special Needs. ICCHP 2018. Lecture Notes in Computer Science, 2018, 10897. Springer, Cham. 
orientation teachers. The third application will be an audio game in which the phenomenon of echolocation will be used. ${ }^{36}$

Simultaneously to the activities conducted by the scientists from Łódź, the Foundation Institute for Regional Development conducts activities aimed at popularizing knowledge about echolocation, developing echolocation teaching methodology and developing practical solutions for training in the field of echolocation under the project "Echolocation for people with visual impairment" (2017-1PL01-KA204-038557) As part of the project, training in echolocation teaching (based on the curriculum proposed by Daniel Kish) covered 12 teachers of spatial orientation from Poland and Lithuania, and a training of 24 people with visual impairment was conducted. ${ }^{37}$ This project is of an international nature, with the participation of spatial orientation teachers from Poland, Lithuania and Denmark. The final goal of the project is to develop a compendium of knowledge about echolocation, a training program for spatial orientation teachers (methodology of teaching echolocation) and recommendations for the implementation of training in echolocation in training in the field of spatial orientation of people with visual impairment. The projects developed in Poland described above are a response to the need for practical use of echolocation in everyday life of people with visual impairment.

\section{Summary}

The use of echolocation ability by people is a phenomenon that is still little known but is increasingly being studied by scientists

36 The works are conducted as part of a project co-financed by the National Center for Research and Development. Witek P., Rozborska A., Waszkielewicz A., Rotnicki M., Brayda L., Echolokacja - mit czy istotny element rehabilitacji osób z niepetnosprawnościa wzroku, [in]: Paplińska M., Walkiewicz-Krutak M. (eds.), Tyflopedagogika wobec współczesnych potrzeb wspomagania rozwoju, rehabilitacji i aktywizacji społecznej, Wydawnictwo APS, Warsaw 2017, pp. 246-247.

37 Detailed information about the project can be found on the Foundation website https:/ / firr.org.pl/projekty/miedzynarodowe/ (access on: 7 June 2019). 
around the world. It becomes particularly significant for blind people, as it allows them to achieve a high level of independence in everyday life. Therefore, which are the benefits of using and developing this skill? First of all, echolocation does not require special equipment or special talent. All people with visual impairment, as well as sighted people can develop this natural, simple ability. ${ }^{38}$ However, in the case of blind people, it can significantly help in creating the correct mental representation of the world (e.g. in terms of spatial relations) based on sound guidance, by determining the exact distances, sizes, shapes, edges and even the density of the surrounding objects. ${ }^{39}$ Moreover, echolocation significantly improves mobility (movement speed, security) in unknown places, making blind people become more independent. ${ }^{40}$

However, despite the aforementioned benefits resulting from the use of echolocation by people with visual disabilities, it is still a phenomenon little known and understood by sighted people. According to the accounts of blind people using echolocation, they often encountered social misunderstanding (misunderstanding of accompanying persons, teachers, etc.), and their echolocation behaviours (smacking their tongue, snapping their fingers, etc.) were assessed as inappropriate behaviour. Probably the reason for such reactions of sighted people is little knowledge about echolocation, its mechanisms and its rehabilitation importance for people with visual impairment. From this perspective, human echolocation seems to be an area that still requires further analysis and research.

38 T. Johnson, Beginner's guide to echolocation for the blind and visually impaired. Learning to See with Your Ears. Create Space Independent Publishing Platform, 2012, pp. 19-21.

${ }^{39}$ D. Kish, J. Hook, Echolocation and Flash Sonar. American Printing for the Blind, 2016, p. 40.

${ }^{40}$ L. Thaler, M.A. Goodale, Echolocation in humans: an overview. "WIREs Cognitive Science", 2016, 7, pp. 382-393. 


\section{Bibliography}

Arias, C., Ramos, O.A., Psychoacoustic tests for the study of human echolocation ability. Appl. Acoust., 1997 51, 399-419.

Arias C., Bermejo F., Hüg M.X., Venturelli N., Rabinovich D., Skarp A. O., Echolocation: An Action-Perception Phenomenon, "New Zealand Acoustics", 2012, 25 (2), p. 20-27.

Bujacz M. et al. EchoVis: Training Echolocation Using Binaural Recordings - Initial Benchmark Results. In: Miesenberger K., Kouroupetroglou G. (eds) Computers Helping People with Special Needs. ICCHP 2018. Lecture Notes in Computer Science, 2018, 10897. Springer, Cham.

Dolański W. Czy istnieje „zmysł przeszkód” u niewidomych. PWN, Warszawa, 1954.

Dyeker, L. O\&M - Flash sonar/ ekkolokalisering. A tutorial for O\&M instructors in Denmark, IBOS, 2014 (unpublished materials).

Fiehler K., Schiitz I., Meller T., Thaler L., Neural Correlates of Human Echolocation of Path Direction During Walking. "Multisensory Research" 2015, 28, p. 195-226.

Goodale M.A., Po co mózg widzi ?, “Charaktery”, 2013, 2, p. 44-45.

Johnson T., Beginner's guide to echolocation for the blind and visually impaired. Learning to See with Your Ears. Create Space Independent Publishing Platform, 2012.

Jorasz U., Wykłady z psychoakustyki. Wydawnictwo Naukowe UAM, Poznań, 1998.

Kish D., Hook J., Echolocation and Flash Sonar. American Printing for the Blind, 2016.

Kolarik A.J., Cirstea S., Pardhan S., Moore B.C., A summary of research investigating echolocation abilities of blind and sighted humans. 2014, "Hear Res", 10, p. 60-68, DOI: 10.1016/j.heares.2014.01.010.

Kuczyńska - Kwapisz J., Znaczenie dźwięku w orientacji przestrzennej niewidomych i słabo widzących. „Normalizacja”, 1997, 2, p. 11-12.

Kuczyńska - Kwapisz J., Śmiechowska - Petrovskij E., Orientacja przestrzenna i poruszanie się osób z niepetnosprawnością wzroku. Wspótczesne techniki, narzędzia i strategie nauczania, Wydawnictwo UKSW, Warsaw, 2017.

Miler-Zdanowska K., Czynniki warunkujace nauczanie orientacji przestrzennej $i$ samodzielnego poruszania się osób z niepetnosprawnościa wzroku, [in:] K. Czerwińska, M. Paplińska, M. Walkiewicz- Krutak, (eds.), Tyflopedagogika wobec wspótczesnych przemian przestrzeni edukacyjnej. Wydawnictwo APS, Warsaw, 2015, p. 289-306.

Miler-Zdanowska, K., Orientacja przestrzenna dzieci z dysfunkcja wzroku - droga do niezależności, [in:] Witczak-Nowotna, J. (ed.), Wspomaganie uczniów z dysfunkcja wzroku w szkołach ogólnodostęnych. Edited by: Office for Persons with Disabilities of the University of Warsaw, Warsaw, 2010, p. 53-61.

Norman L.J., Thaler L., Human Echolocation for Target Detection Is More Accurate With Emissions Containing Higher Spectral Frequencies, and This Is Explained by Echo Intensity, "i-Perception”, 2018, 9(3), p. 1-18, DOI: 10.1177/2041669518776984. 
Rojas J.A.M., Hermosilla J.A., Montero R.S., Espí P.L.L. Physical analysis of several organic signals for human echolocation: hand and finger produced pulses. "Acta Acustica united with Acustica", 2010, 96, p. 1069-1077.

Supa, M. Cotzin, M., Dallenbach, K.M. Facial vision, the perception of obstacles by the blind. American Journal of Psychology, 57, 1944, p. 133-183.

Schenkman B. Nillson M.E., Human echolocation: Blind and sighted persons' ability to detect sounds recorded in the presence of a reflecting object, "Perception", 2010, 39, p. 483-501.

Schenkman B., Human echolocation in different situations and rooms. The Journal of the Acoustical Society of America, 2017, 141(5). 3452-3452, DOI: 10.1121/1.4987156.

Theng S., Whitney D., The acuity of echolocation: Spatial resolution in the sighted compared to expert performance, Journal of Visual Impairment \& Blindness. 2011, 105(1), p. 20-32.

Theng S., Human Echolocation, ProQuest Dissertations Publishing, University of California, Berkeley, 2013, p. 1-6.

Thaler L., Goodale M.A., Echolocation in humans: an overview. "WIREs Cognitive Science", 2016, 7, 382-393, DOI: 10.1002/wcs.1408.

Wiener W.R., Lausen G.D., Audition for the Traveler Who Is Visually Impaired, [in:] B.B. Blasch, W.R. Wiener, R.L. Welsch, (eds.) Foundations of Orientation and Mobility, 1997, A.F.B. Press: New York, 104-169.

Witek P., Rozborska A., Waszkielewicz A., Rotnicki M., Brayda L., Echolokacja mit czy istotny element rehabilitacji osób z niepetnosprawnościa wzroku [in]: Paplińska M., Walkiewicz-Krutak M., (eds.) Tyflopedagogika wobec wspótczesnych potrzeb wspomagania rozwoju, rehabilitacji i aktywizacji społecznej, Wydawnictwo APS, Warsaw 2017. 